\title{
The Contribution of the Press to Europeanization of Public Debates
}

\author{
A Comparative Study of Issue Salience and Conflict Lines of European Integration \\ By Barbara Pfetsch, Silke Adam and Barbara Eschner
}

\begin{abstract}
In our study we seek to understand how national political contexts and different media formats constrain the role of the press in contributing to a Europeanisation of national public spheres. To single out the explicit role of different newspapers in seven Western European countries we systematically compare their commentating about European integration. The role of the press is analyzed with respect to the visibility of European issues and actors and to the synchronization of conflict lines across Europe. The results show that the further a country is integrated into the European Union, the less parochial is its press and the stronger it takes part in a common European debate. Compared to these political settings the influence of specific press formats seems to play a secondary role.
\end{abstract}

Key words: European public sphere, press commentary analysis, comparative political communication, media formats, political contexts 


\section{Introduction}

A space for deliberation, discussion and engagement in societal issues, a public sphere, is crucial for democratic polities. As long as the shift of competences to the European Union was limited and as long as a permissive consensus among the public accompanied this shift, scholars were hardly interested in a common European space for public debate ${ }^{1}$. As the competence shift has accumulated and the permissive consensus declined, researchers now search for the development of such a sphere in Europe as a source of legitimacy, accountability and an instrument for collective identity building (e.g. Gehards 1993, Risse and EngelmannMartin 2002).

Most social scientists today agree that a pan-European public sphere involving the average citizens is unrealistic (de Vreese 2007: 8). Instead such a European public sphere relies on national mass media and their ability or willingness to contribute to the Europeanisation of national public spheres (Neidhardt et al. 2000). Our study is part of the rich strand of re$\operatorname{search}^{2}$ that analyzes the degree of Europeanization of national public spheres across Europe and seeks to understand the factors triggering such Europeanization. However, our intention is not - as most studies do - to highlight the role of the media as conveyors of news about Europe. Instead, we focus on the media as political actors (Page 1996, Pfetsch and Adam 2008) who among other actors like governments, parties, interest groups or civil society actors make their own contributions to public debate and in their editorials legitimately raise their own voice about European integration. This focus on the press' own voice is a pressing desideratum. Research on the performance of the press allows us to determine whether the media must be blamed for the lack of a European public sphere or whether other factors are responsible. In addition, such an analysis is pressing since we know from empirical studies that news commentators have a significant impact on public opinion (Page et al. 1987). To study the role of the media as actors, we draw on the two central dimensions that have been discussed 
in studies of Europeanization: the synchronization of debates across countries and the references to EU and member state actors and issues within each country (Adam 2007a, Tobler 2002, van de Steeg 2002). We study editorials of the quality, the regional and the boulevard press regarding their degree of Europeanization in six member countries of the EU (France, Germany, Italy, Netherlands, Spain, United Kingdom) and in one non-member (Switzerland). This research design allows us to evaluate whether the press' own voice more strongly reflects a country's specific political context or the format of an outlet.

In introducing our study and its findings we proceed in three steps: We begin with discussing the indicators that are crucial to describe the Europeanisation of national public spheres. The role of the media is highly constrained by the political context and the media format as we demonstrate in the study. These two factors help us develop expectations for our empirical study which we introduce in its design and methodology. As the role of the media in building up a European public sphere is epitomized in the commentaries on the European integration issue we turn to this issue in order to test our expectations. The empirical findings relate to 1409 commentaries on EU integration in 27 newspapers across seven countries and compare these to the broader editorial agenda of these newspapers (5063 commentaries) in the period over three years from 2000 to 2002.

\section{Theoretical Considerations and Expectations}

To evaluate media's role in the Europeanization of national public spheres, we draw on two core ideas that seek to describe a common forum of communication across European countries. First, national debates are regarded Europeanised if they open up their communicative space for issues and actors from the EU and other member states. Such an opening may contribute to connect Europe by communicative interactions (Habermas 2001: 120; Koopmans and Erbe 2004). From a normative point of view, Europe needs visibility for the debate about 
issues of transnational concern and issues that are at stake between European countries on the elite and citizen levels. Only if citizens have the chance of becoming aware of the relevance of European topics and actors, can we speak of an interconnected European debate (Koopmans and Erbe 2004, van de Steeg 2005, Adam 2007a). The second often-cited criterion to identify processes of Europeanization in national mass media refers to synchronization. Debates are regarded as Europeanised if they converge across Europe. A European communicative space in this perspective requires that issues are debated at the same time under similar points of reference in different European countries (Eder and Kantner 2000). The synchronization refers to a shared system of meaning and would give European citizens a common basis for decisions.

Regarding the visibility of EU issues in public we draw on two indicators: The first refers to the capacity of media to attribute salience to topics of EU integration on the national editorial agenda. Media may enhance Europeanization by highlighting the issue of EU integration prior to other issues on the commentary agenda. Such an analysis allows us to gauge the media's willingness to discuss EU issues at all. The second indicator refers to media's potential of opening up public debate for European actors and their perspectives. By providing space for the transnational actors in their commentaries, the media prevent the closure of the debate and contribute to overcoming purely national scopes. This dimension places cross-border flows of communication at the center of attention. In fact, we may treat the media as an engine of Europeanization, if they overcome their parochial nationally confined angles and reach beyond the territorial state (Koopmans and Erbe 2004).

Considering the synchronization of European debates the question is whether media do not only discuss common issues, but also discuss these issues with respect to similar political frames. One way to capture the frames of political issues is to relate them to the general polit- 
ical conflict lines and policy options that structure the political debate in a given country (Voltmer (1998/99: 78ff.). Originally, conflict lines resonate with ideological left versus right cleavages. As European policy has not yet created such a clear-cut left-right cleavage, we will introduce conflict lines relevant for EU integration in the empirical part of the paper. In our study, two indicators are used to determine whether the topic of EU integration is discussed with similar points of reference across EU countries: First, we examine whether national media agree on the relevant conflict lines that need to be addressed as regards EU integration. Second, we analyze whether the media advocate the same positions on these conflict lines.

As we study the role of the media in Europeanization we must take into account that processes of political communication are highly context sensitive (Esser and Pfetsch 2004:393-399). Gamson and Lasch (1983: 397) point out, that every political discourse exists within a certain 'issue culture' in which groups and individuals use a catalogue of available idea elements and make use of a variety of symbolic devices to express their ideas. National media as actors are not independent of these issue cultures nor are they separate from the political culture that prevails within their country. The involvement of the media with national issue- and political cultures is essential with respect to the interpretation of European integration issues. Hence, Diez-Medrano's study (2004) demonstrates that the media's frames of Europe represent the long-term expectations of the impact of European integration on national collectivities. The importance of the national level is also highlighted by other studies (Peter et al. 2004a; Peter and de Vreese 2004b, Adam 2007a /b).

If we take into account that national political cultures are engrained in the nature of how European issues are interpreted we should expect differences across countries in press commentary. Perhaps the most basic, but probably also one of the most crucial factors that shape national political cultures with regard to EU integration is the depth of integration. Europeaniza- 
tion by the media can thus be regarded as interlinked with the political and economic involvement of a country into the project of European integration. We assume that the media in countries that are fully involved into the project of European integration, attribute more salience to the topic of EU integration, show European and member state actors more strongly and discuss different conflict lines compared to media in countries that can be regarded as hesitant members or that have not (yet) joined the EU (H1).

The second aspect that may constrain the role of the media in Europeanization is inherent in the segmentation of the media system (Hallin and Mancini 2004). This segmentation is of political relevance for the Europeanization of the public sphere. There is evidence that the division between the press and television as well as the division between the quality press and the boulevard press or between public and private broadcasting does play a role in the representation of European issues (Kevin 2003, Peter and de Vreese 2004b, Peter et al. 2004a, de Vreese 2007): public television more strongly contributes to Europeanization than private television, quality newspapers outperforms tabloid newspapers. Hence, we can expect to observe variation in issue salience, variation in openness towards European and member state actors and variation regarding the relevance of and positioning on conflict lines within a national media system. Regarding the press we hypothesize that the regional and the tabloid press tend to be more parochial and more eurosceptic than the national quality press $(\mathrm{H} 2)$. We expect the tabloid press to hook up on rather eurosceptic sentiments which in some countries are affiliated with rather populist attitudes about European politics. The regional press targets a readership more interested in local issues. It is known on the other hand that the national quality press caters to the national political elites, who are those carrying EU integration.

\section{Data and Methodology}

To capture the performance of the press in the Europeanization of national public debate, we 
study editorials and press commentaries with the tools of quantitative content analysis. ${ }^{3}$ In our terminology, each editorial or commentary is recorded as one claim of a journalist in which he or she makes demands. Following Koopmans and Statham (1999), a claim is defined as a unit of strategic action in the public sphere that consists of the purposive and public articulation of political demands. The coding of an editorial or commentary as media claim usually consists of the following variables: (a) the commentator; (b) the addressees, who are held responsible or are the target of criticism or support; (c) the affected actors, whose interests are or would be positively (beneficiary) or negatively affected by the claim; (d) the topics and (e) the frames and conflict lines the claim refers to. Since one can assume that the editorials represent the political and ideological commentary line of each newspaper, we take the aggregation of claims by individual commentators as the position of the media outlet as such.

In our study we chose an issue-specific approach to public debate. It draws on the idea that a Europeanization of national public spheres develop - if at all - around issues, where competences have been shifted to EU levels (see Kunelius and Sparks 2001: 18; Koopmans and Erbe 2004). We maintain that analysing the issue field of EU integration gives us the clearest indicator of the press' role in Europeanization. However, we are aware of the fact that also debates on other issues in culture, economy or social affairs need to become Europeanized for the development of a fully fledged European public sphere. An editorial was chosen for analysis if it focused explicitly on the integration process and not on substantial issue fields like monetary or agricultural politics. Editorials on EU integration deal with structural or cultural questions of the EU (e.g. relationship between EU and national levels or identity questions) and with core tasks and future challenges of the integration process.

To measure our three indicators of Europeanization - issue salience, openness and conflict lines - two levels of analysis are necessary. On a first level of analysis, we look at the overall 
editorial agenda, which allows us determining the relative salience of EU integration as a topic compared to other issues. We investigate the salience of the press' commentating on the issue field of EU integration and compare it to the salience of commentating in six other issues fields, namely agriculture, monetary, immigration, troops deployment, pensions and education.

On a second level of analysis, we concentrate our efforts on those commentaries that deal with EU integration. For these editorials we fully use our claims coding. Claims have a relational structure which reveals the actor constellations within an issue field. Journalists as claimants attribute responsibility, support and critique to specific addressees. In addition, claimants define whose interest would be positively or negatively affected by their claim (affected actors). The type of actor constellation thus reveals whether the press opens up their communicative space by including transnational and European actors and thus makes Europe visible. Additionally, claims capture the conflict lines which the claimants respectively journalists employ. This variable allows us identifying whether the press in Europe uses similar points of reference when discussing European integration. Employing the same conflict lines however does not necessarily imply having the same opinions. Only by studying the press' positioning on these conflict lines, we can judge whether the press in Europe serves as advocate for the same ideas of EU integration.

Our research design seeks to exploit the advantage of comparative cross-country and crossmedia studies which allows us evaluating the impact of national political contexts and media formats. On the country dimension, we included the press of Germany, France, Italy, the Netherlands, Spain, Switzerland and the United Kingdom. Following our hypothesis regarding the depth of integration (H1), this selection of countries leads us to expect that commentaries differ between three groups of countries. First, there is the continental European group 
constituted by Germany, France, Italy, the Netherlands and Spain. These countries are - with the exception of Spain - founding members of the European Union. In addition, all of them have joined the common currency union, the Schengen agreement and thus can be regarded as fully involved into the integration project. A second country category is constituted by the United Kingdom which is one of the most hesitating members of the EU regarding the shift of competences. By staying outside central projects as the common currency or the Schengen agreement, the UK has decided to limit the depth of integration within the EU. The third country category consists of Switzerland. The Swiss have not joined the EU but are narrowly linked with the Union by bilateral agreements. The uneven placement of countries into the specified groups shows the limitations of our data. We are aware of the fact, that to fully test for the depth of integration thesis more countries need to be included in those categories that have limited the depth of integration as EU-members (e.g. the new accession states) or nonEU members (e.g. Norway).

On the format dimension, we selected four daily newspapers of different types in each country: a centre-left as well as a centre-right quality newspaper, a tabloid newspaper, as well as a regional newspaper in a region with a specific regional identity ${ }^{4}$. Analyzing only one regional newspaper per country can only be a starting point for testing how press formats differ or converge regarding Europeanized commentating. Nevertheless, we expect a clear-cut difference between the quality newspapers and the regional/boulevard press in each country (H2). An overview of the 27 newspapers under study is provided in appendix A1.

The editorials ${ }^{5}$ of the 27 newspapers were analyzed for a three year period between 2000 and 2002. Our selection resulted in 1409 commentaries for the issue field of EU integration and 5063 for the broader editorial agenda of these newspapers constituted by seven issue fields under study. The editorials were coded by native speakers who were carefully trained before 
coding and supervised throughout. For the reliability test, coders in each country team coded a random sample of seven commentaries from the Scotsmen, the Times and the Guardian of the year $2002 .^{6}$ The inter-coder reliabilities were measured as the average match between the coders. The overall reliability calculated on the core variables of the analysis turned out to be highly satisfactory with an average match of $75 \%$. The reliability for specific variables is indicated at the bottom of the respective tables or figures.

\section{Findings}

Issue Salience of European Integration on the Commentary Agenda

In a first step we assess the relative salience of the issue of EU integration compared to the six other issues of our study to measure the press' role in the Europeanization of national public spheres. ${ }^{7}$ As each issue field has been defined differently in breadth, we shall not compare the results regarding issue salience within a country, but highlight the differences in the relative salience attributions between the seven countries under study. ${ }^{8}$

\section{Table 1 here}

The findings on the relative salience of European integration in press commentaries allow for discriminating three groups of countries. First, the press in Germany, Spain, France, Italy and to a lesser degree the Netherlands reveal a substantial share of commentaries on EU integration: between 26,5 and $42,3 \%$ of all analyzed commentating refers to the issue field of European integration. Second, the British press devotes a lesser amount of commentating to EU integration than the newspapers of the continental European countries. Third, contrary to our first hypothesis (H1), the press in the non EU-member state Switzerland attributes high salience to EU integration. More than $40 \%$ of all coded commentaries in the period under study in Switzerland deal with the issue of EU integration. The press' strong commentating on the 
relationship between the country and the European context reflects the fact that the dispute on sovereignty versus transnational integration has become the key cleavage of Swiss society over the past decade (Kriesi et al. 2006).

Following our hypothesis regarding different newspaper types (H2), we expect that the quality press is the one that puts the topic of European integration more prominently on the agenda than the regional or tabloid press. Table 1 shows, that this is the case for all countries in the continental group except for France. In these countries quality newspapers attribute a higher share of the overall commentating to the issue field of European integration than do regional or tabloid newspapers. The biggest gap can be seen in Italy: here regional newspapers devote $25 \%$ of their commentating regarding the seven issue fields under study to the topic of European integration, whereas the quality newspapers' share amounts to more than $37 \%$. For the United Kingdom and Switzerland we must reject the hypothesis as the quality press does not attribute more attention to the field of EU integration. Moreover, the tabloid press in these countries puts as much - in the UK even more emphasis - on the issue field of EU integration than the quality newspapers. It seems that in countries where the depth of integration is a contentious issue, the tabloid press is a front-runner to present this polarization.

\section{Openness of Actor Constellations in Commentaries on European Integration}

Focusing only on commentaries on European integration, we can show how the press performs in making European and member state actors visible. In commentaries, newspapers talk about an issue thereby defining who is responsible for solving a problem (addressee) and who is affected or concerned by the problem or its solution (affected actors). We see whether the national media open up the communicative space for transnational actors - and thereby transcend the limitations of the national debate. 
In the analysis of the openness of the media debate towards European actors, we proceed in several steps. In a first step, we computed a summary variable that measures to what degree the press attributes responsibility (addressee) and concern (affected actor) to actors beyond the nation state. In order to identify the scopes of actor constellations, we divided the editorials on European integration into four categories. First, we can identify commentaries that only mention addressees and affected actors who come from the EU, EU-member states or upcoming EU-member states. These editorials are regarded as fully Europeanised. The second category refers to commentaries that name only one European actor either as addressee or as affected actor. They are referred to as partly Europeanised. Both types of commentaries are contrasted with editorials that only include national actors on the one hand and those that include international, but not European actors.

\section{Figure 1}

Regarding the openness of actor constellations, we can distinguish at least two, perhaps also three groups of countries. The five EU-countries on the continent once again constitute a relatively homogenous group. The newspapers of Germany, Spain, France, Italy and the Netherlands are quite open in their actor constellations. Hence, between one half and two thirds of the commentaries in European integration politics are fully Europeanized. We also see that the press in Germany, France and Italy seldomly restricts the picture by focussing on national perspectives only, as the share of fully national editorials is less than $10 \%$. In Spain and the Netherlands the actor constellation is somehow more nationally contained, which is indicated by a share of around $20 \%$ fully national claims. Figure 1 allows us to rank the countries within this group according to their openness towards European actors: Thus, we see that the press in France and Italy opens the communicative space strongest. The German press which is similar to France and Italy in the (rather low) level of featuring only national claims, shows a 
stronger tendency to involve actors from non-EU countries, particularly from Turkey. The Dutch and the Spanish press that also belong to the group of countries with rather Europeanised actor constellations show the highest mention of national claims. Compared to the continental EU-member states' press, the British newspapers once again must be described as a contrasting case. In the UK fully Europeanised claims make up for only $25 \%$, whereas $45 \%$ of claims are completely confined to national actors. The British press thus does not only avoid discussing the topic of EU integration, but also closes its communicative space. Interestingly, in this respect the UK is similar to Switzerland. The Swiss debate on EU integration is strongly bound to the nation state. Nearly $55 \%$ of the press' claims in Switzerland must be categorized as fully national.

The aforementioned patterns of openness of actor constellations across countries also hold up if we include the newspaper type into the picture (table 2). Comparing the mean score of openness within countries between the tabloids and regional press on the one hand and quality newspapers on the other hand, we hardly find differences in the continental EU member states. In contrast, while the United Kingdom and Switzerland already engage in a rather parochial pattern of actor constellations, the tabloid press turns out to be the frontrunner in this process.

\section{Table 2}

In order to test the significance and the strength of variation in the degree of Europeanization in commentating across countries and newspaper types, we conducted an analysis of variance (MCA). The analysis shows that the level of Europeanization varies significantly across countries (Beta .34). Due to the parochial style of commentating of the British and Swiss tabloid newspapers, a significant but lower difference is also found between newspapers (Beta .11). 
Thus, we can also confirm the differences between quality, regional and tabloid newspapers with respect to the openness of the debate on European integration. The beta values however indicate that the differences between countries turn out to be more important than those between newspapers.

\section{Conflict lines in Commentaries on European Integration}

To explore whether the press discusses similar questions and advocates similar positions regarding the topic of EU integration, we draw on the approach of conflict lines proposed by Voltmer (1998/99:78f). The instrument was revised to account for the conflict lines (CL) in disputes on EU integration. ${ }^{9}$ The dimensions underlying the conflict lines can be seen in appendix table A2.

The first conflict is a fundamental one dealing with the membership question: Should a country become or remain a member of the European Union or should it reject or withdraw from the integration process in general (CL1)? Another type of conflict deals with institutional power questions. These questions refer to the relation between the member states (CL2) and the relation between the supranational and the national level (CL3). Should member states have an equal say or should there be the possibility that some member states proceed while others remain behind? Should integration strengthen the supranational level or the national, i.e. intergovernmental, level? Another type of conflict discusses citizens' role in EU integration. Conflict line four (CL4) deals with the relation between the European Union and the citizens and thus highlights the often-mentioned democratic deficit of the European Union. The basic line of conflict here is whether citizens' rights should be extended or whether these rights should remain as they are. Conflict line five (CL5) refers to the social base for EU integration. EU integration, as some argue, needs citizens whose identities are not solely bound to the nation state anymore (see e.g. Scharpf 1999: 672). Others state that it is sufficient for Eu- 
ropean integration if citizens remain with a purely national identity. Another type of conflict refers to the general goals of EU integration. On the one hand there are those who emphasize the enlargement of the Union while at the same time accepting a slowing down of the deepening process. On the other hand there are those who see the main goal of the European Union in deepening the integration process, stepping beyond the economic integration and aiming for a politically unified Europe. Deepening is thus more important than further enlargement of the EU (CL6). The last type of conflict connects the topic of EU integration to arguments in substantial policy fields. Here the role of the EU constitutes the center of the basic conflicts. Within monetary and foreign policy, one can propose that the EU has a strong role in shaping these fields or that the EU stays out leaving the steering to national actors (CL7 and CL8). Regarding social policy, the EU can be seen as a provider of welfare or as a liberal marketdriven union that avoids any state intervention into economic processes (CL9).

Table 3 shows the conflict lines that dominate the debate on EU integration in the press. The groups that have been identified for the salience question are confirmed with regard to the distribution of conflict lines. In the press of the continental European countries the topic of EU integration is discussed in terms of two dominant conflict lines. On the institutional dimension the arguments center on how the relation between the member states and the European Union should look like. Additionally, commentating on EU integration refers to the goals of the integration project, what equals the question of enlargement versus deepening. 65 to $80 \%$ of all conflict lines employed by the press in Germany, Spain, France, Italy and the Netherlands in the issue field of EU integration refer to these two basic dimensions. The second group constituted by the United Kingdom in contrast, debates the topic of EU integration in another way. Whereas the continental European press agrees on the two central questions that further EU integration must answer, the British press does not. While attributing some importance to these questions too, the British press discusses the role of the European 
Union mainly in the light of two substantial issue fields, foreign and monetary policy. Questions concerning the EU's institutional design and future shape seem to have a hard time to gain attention in the British press. Primarily the discussion on the common currency seems to concur with the debate on EU integration. The British press thus sticks to a debate that has long been finished in continental Europe. The UK newspapers hardly take up new issues and ongoing arguments that have shaped the debate in the Brussels arena at the time of our analysis: On the continent, questions of possible forms of integration were hotly debated when searching for a common European Constitution and when preparing the Union for the largest enlargement round ever in its history. Eventually, the press of the non-EU member state Switzerland - not surprisingly - is the only one that does not show interest in the form of EU integration. It sticks to the basic conflict of whether Switzerland should become more strongly involved into the integration project or remain outside. Interestingly enough, questions of European integration are hardly debated in any country in light of the often referred to democratic deficit of the Union and they hardly focus on the relation between the member states.

\section{Table 3 here}

Further detailed analysis about the conflict lines in the various newspaper formats ${ }^{10}$ reveal that with the exception of Italy and the Netherlands, regional and tabloid newspapers in the continental EU-countries present a more simplified picture of conflict lines related to EU integration than does the quality press. If the German, French and Spanish regional press or boulevard newspapers employ conflict lines on the topic of EU integration at all, they attribute around twice as much attention to the enlargement-widening conflict than does the quality press. In the UK the Euro is a strong issue of concern of the boulevard and regional press, whereas the quality press' attention here is much lower. The same scheme holds for Switzer- 
land where the nation is divided on how to relate to the EU at all. This fundamental conflict is more salient in the regional and boulevard press.

Our further analysis reveals that the press of the continental European countries strongly advocates a supranational model of integration against an intergovernmental one. An interesting case here is France, where the political elite is deeply divided on the question which role the 'grand nation' should have in a further integrating Europe (e.g. Goulard 2002). The press in contrast strongly pleas for a supranational model of EU integration thus breaking with the French tradition that places the nation state in the centre of political thought. Regarding the question of enlargement versus deepening, Table 4 indicates that the continental European countries stress the importance of deepened integration before enlargement. The British press can be regarded as a contrasting case since it supports an intergovernmental Europe. It is always stressed that the nation state should prevail over any common regulations - be it in foreign or monetary matters or in the general relation to other member states. In addition, the British press places the enlargement of the Union at the centre. The clear distinction between the country groups supports the idea that media reflect national political cultures towards the EU. Nevertheless, the French case can be regarded as a first example, that a more closed-up picture might reveal differences between national political cultures and the press' positioning. This is supported by the results from Switzerland. Surprisingly, the Swiss press supports in unison a stronger involvement into the European Union which is not reflected in public nor elite opinion.

\section{Table 4}

When comparing the quality newspapers with the regional and tabloid press within a country we find a strong consensus about the positioning on the conflict lines, which leads us to reject 
hypothesis 2 on this dimension. Quality newspapers and regional / tabloid newspapers do not support opposing extremes of specific conflict lines. There is only one case of difference between the quality and tabloid / regional newspapers: When EU integration is discussed in the $\mathrm{UK}$, the quality press asks for common policy arrangements in foreign policy whereas the tabloids and regional press remains more parochial by demanding national autonomy.

\section{Conclusion}

The analysis has shown that the press contributes - in different levels and degrees - to the Europeanization of national public spheres: the issue of EU integration is salient on the commentary agenda, it is discussed with some form of openness towards the European level and at least within the continental European press there is consensus not only on the questions that need to be answered but also on the positions to be advocated.

If we try to understand the variation in national media's degree of Europeanization, a country's depth of integration $(\mathrm{H} 1)$ has turned out as more relevant as different media formats (H2). It has been shown that the press attributes higher salience to Europe in those countries that are involved in all major integration projects. With its high level of attention to EU integration, the Swiss press however shows that there is a second way to deal with Europe if a country is not or not fully integrated apart from the British reaction of parochial closure. Thus, the depth of integration cannot be the only factor that explains variation in the press' attention to EU integration. The depth of integration also impacts the actor constellations presented. In the stronger integrated countries the press attributes responsibility more strongly to European actors than to national ones. In contrary, the British and the Swiss press stick to parochial commentating. 
The importance of the national political context becomes most salient when studying conflict lines and positions. In the continental European countries the press does not only agree on the most urgent questions that the further process of integration has to deal with, but also on the answers to these questions. The press in the five continental European countries calls for a supranational model of integration where the deepening of integration is judged more important than enlargement. The press in the United Kingdom in contrast stresses all conflict lines that allow highlighting the importance of sovereignty. Finally, the membership question is the one discussed by the Swiss press. Interestingly, the Swiss press - in contrast to the elite and the public - calls in unison for stronger Swiss involvement. These textual frames are a clear sign that a more distanced discussion on Europe dominates in the United Kingdom and Switzerland, whereas the press in the other countries seems to comment on the core questions that the EU currently faces and thus fulfil the requirement of synchronization.

Interestingly enough, we do not find these clear-cut cross-national differences within our countries. Quality newspapers are not as distinct from regional and tabloids as we expected. As regards positioning we find for example that the quality press like the regional and boulevard outlets in a country argue more or less within the same conflict lines. With one - small, but interesting - difference: Regional and tabloid newspapers tend to stress those conflict lines that are of greater concern to a broad population (e.g. the question of enlargement in France, Germany and Spain).

As a consequence thereof, it seems too easy to solely blame the press for not contributing to Europeanization. Instead, our analysis confirms that factors external to the media have a strong impact on shaping the press' own voice: different press titles within a country reflect on the same political setting. The depth of integration is one crucial factor that helps us understand the press' own voice in a country. However, although we did not find systematic and 
consistent variation within the group of fully integrated countries, we are sure that more context variables play a role (see e.g. Adam 2007a /b, Peter et al. 2004a; Peter and de Vreese 2004b).

If we discuss our findings with respect to the larger picture of media`s performance in building up a European public sphere, we may rather be optimistic about the willingness of the print media to function as agents of transnational political communication within the EU. Our study shows that in the countries that can be regarded as inner circle of the EU the press appears to form a European voice that makes Europe visible and argues with similar vigour and in a similar direction. It makes European topics and actors visible and converges regarding the conflict lines discussed and positions advocated. The British and the Swiss cases however show that this potential to form a common space of communication depends on large parts on the political context of the debate. The further a country is integrated within the European community, the stronger the press takes part in a common European debate. A first precondition for European debates is thus not - as Gerhards claims (2000: 292) - the full democratization of the EU. Instead, we find that common political structures and institutions are most likely to trigger the national press' attention for European issues and openness towards transnational European scopes. Compared to these political settings the influence of specific media formats seems to play a secondary role. However, the results also show that the depth of integration and the type of media are not sufficient to fully explain differences and commonalities in the commentating on EU integration. Comparative research - be it cross-national, crossmedia, cross-issue - may further disentangle these processes. 


\section{Notes}

1 We limit our considerations here to a European sphere that focuses on the European Union - not on Europe per se. As communicative spaces should - from a normative point of view - extend to the same area as political decision-making power, this sphere is the most relevant at least for EU-member countries.

2 E.g. Adam 2007a /b, Berkel 2006, Brantner et al. 2005, de Vreese 2003, Gerhards 2000, Kevin 2003, Kleinen von Königslöw et al. 2005, Koopmans and Erbe 2004, Koopmans and Pfetsch 2006, Peter and de Vreese 2004b, Peter et al. 2004a, Pfetsch 2007, Trenz 2005, van de Steeg 2005.

3 The data stem from a larger research project called 'Europub'. This project was sponsored by the EU Commission (HPSE-CT2000-00046). A project description (Koopmans and Statham 2002), the codebook (Adam et al. 2002) and project reports can be found at http:// europub.wz-berlin.de.

4 In particular, we faced some difficulties with regard to the tabloids, since there are different cultural notions about tabloids in the various countries. For instance, not all national media systems reveal such a sharp contrast between quality newspapers and tabloids like Germany, Switzerland or the UK. In countries where the media landscape does not feature a clear cut yellow press, we tried to select newspapers for the study that can be regarded as functional equivalents to the tabloid press. In countries where we could not identify such a functionally equivalent newspaper, we chose a second regional press title.

5 To reach a sufficient number of commentaries in all countries for coding and still be able to fulfill the workload of coding in those countries with a high number of commentaries, we decided to customize the samples for each country's setting. We decided on the following strategy: In those countries with a low number of commentaries, France, the Netherlands and Switzerland, we selected all commentaries that fit our seven issue fields (EU integration, agriculture, monetary politics, immigration, troops deployment, pensions, education) in all of our four newspapers on every day of the year. In the United Kingdom, Italy and Spain - countries that yield a medium number of commentaries - we select and register the commentaries on average three days per week. Germany turned out to be the country with most commentaries. Thus we decided here to analyze commentaries on three days in two weeks. On the days of the sample we looked through all four newspapers and selected all commentaries related to the seven issue fields. These sampling schemes have been applied to all the years under study. 
6 Commentaries are defined in the strict sense as the opinion articles written by a journalist or editor of the newspaper. They appear every day, often in a specific layout. These strict criteria make them easily identifiable. Therefore the selection was not tested.

7 As editorials sometimes connect different topics, we allowed coding the three main topics within each editorial. If at least one of them referred to the topic EU integration, we included it under the label "EU integration". However, most of the analyzed editorials within the category "EU integration" were coded in the first, what means 'most important issue' category.

${ }^{8}$ We are aware of the fact, that we cannot judge the salience of the issue field EU integration on the overall commentary agenda. Nevertheless, we think that a seven-issue sample can serve as an indicator for the relative salience of the issue field within a country.

9 This instrument of analysis is likely not to exhaustively capture the disputes on EU integration so far. It needs further testing and refinement. However, we claim, that this instrument represents a crucial step towards analysing debates on EU integration in more detail, revealing media's positions.

10 The data that show how each single newspaper employ conflict lines has not been included in the tables (table 3 and 4) as otherwise the tables would have been hardly readable. The data on formats and conflict lines can however be directly obtained from the authors. 


\section{Bibliography}

Adam, Silke (2007a) Symbolische Netzwerke in Europa. Der Einfluss der nationalen Ebene auf europäische Öffentlichkeit. Deutschland und Frankreich im Vergleich [Symbolic networks in Europe. The impact of the national level on a European public sphere. Germany and France in comparison]. Köln: Halem.

Adam, Silke (2007b): Domestic adaptations of Europe. A comparative study of the debates on EU enlargement and a common Constitution in the German and French quality press. International Journal of Public Opinion Research 19 (4): 409-433.

Adam, Silke; Barbara Berkel; Julie Firmstone; Emily Gray; Ruud Koopmans; Barbara Pfetsch and Paul Statham (2002) 'Codebook for content coding of commentaries / editorials', http://europub.wzb.eu/Data/Codebooks\%20questionnaires/D3-1-commentarycodebook.pdf, consulted March 2005.

Berkel, Barbara (2006) Konflikte als Motor europäischer Öffentlichkeit. Eine Inhaltsanalyse von Tageszeitungen in Deutschland, Frankreich, Großbritannien und Österreich [Conflict as driving force for a European public sphere. A content analysis of newspapers in Germany, France, the UK and Austria]. Wiesbaden: VS.

Brantner, Cornelia; Astrid Dietrich and Florian Saurwein; (2005) 'Europeanization of National Public Spheres: Empirical Evidence from Austria'. Paper presented at the First European Communication Conference, November 24-26, Amsterdam.

De Vreese, Claes H. (2007) 'The EU as a public sphere'. Living Rev. Euro. Gov. 2(3). http://www.livingreviews.org//reg-2007-3, cited 01/08 
De Vreese, Claes H. (2003) Framing Europe. Television news and European integration. Amsterdam: aksant.

Diez-Medrano, Juan (2004) Framing Europe. Attitudes to European Integration in Germany, Spain, and the United Kingdom. Princeton: Princeton University Press.

Eder, Klaus and Cathleen Kantner (2000) ,Transnationale Resonanzstrukturen in Europa. Eine Kritik der Rede vom Öffentlichkeitsdefizit [Transnational structures of resonance in Europe. A critique of talking about a deficit of the public sphere]' Kölner Zeitschrift für Soziologie und Sozialpsycholgie. Sonderheft 40: 306-331.

Esser, Frank and Barbara Pfetsch (2004) 'Meeting the Challenges of Global Communication and Political Integration: The Significance of Comparative Research in a Changing World', pp.384-410 in F. Esser and B. Pfetsch (eds) Comparing Political Communication: Theories, Cases, and Challenges. New York: Cambridge University Press.

Gamson, William. A. and K.E. Lasch (1983) 'The political culture of the social welfare policy', in S. E. Spiro and E. Yuchtman-Yaar (eds.) Evaluating the welfare state: social and political perspectives. New York: Academic Press: 397-415.

Gerhards, Jürgen (2000) ,Europäisierung von Ökonomie und Politik und die Trägheit der Entstehung einer europäischen Öffentlichkeit [Europeanization of economy and politics and the indolence of an emerging European public sphere]'. Kölner Zeitschrift für Soziologie und Sozialpsychologie. Sonderheft 40: 277-305. 
Gerhards, Jürgen (1993), Westeuropäische Integration und die Schwierigkeiten der Entstehung einer europäischen Öffentlichkeit [West-European integration and the difficulties in the development of a European public sphere]'. Zeitschrift für Soziologie 22 (2): 96110.

Goulard, Sylvie (2002) ,Frankreich und Europa: die Kluft zwischen Politik und Gesellschaft [France and Europe: the gap between politics and society]', pp. 173-195 in M. Meimeth and J. Schild (eds.) Die Zukunft von Nationalstaaten in der europäischen Integration. Deutsche und französische Perspektiven. Opladen: Leske+Budrich.

Habermas, Jürgen (2001) Zeit der Übergänge. Kleine Politische Schriften IX [Times of transitions. Small political writings]. Frankfurt am Main, Suhrkamp.

Hallin, Daniel C. and Paolo Mancini (2004) Comparing Media Systems. Three Models of Media and Politics. Cambridge: Cambridge University Press.

Kevin, Deirdre (2003) Europe in the Media. A Comparison of Reporting, Representation, and Rhetoric in National Media Systems in Europe. London: Lawrence Erlbaum Associates.

Kleinen von Königslöw, Katharina; Michael Brüggemann; Stefanie Sifft and Andreas Wimmel (2005) ‘The Europeanization of Public Spheres: Each Country on its Own?’ Paper presented at the 55th Annual Conference of the International Communication Association, 26.-30. May. New York. 
Koopmans, Ruud and Barbara Pfetsch (2006) 'Obstacles or motors of Europeanization? German media and the transnationalization of public debate'. Communications 31: 115138.

Koopmans, Ruud and Jessica Erbe (2004) 'Towards a European public sphere? Vertical and horizontal dimensions of Europeanised political communication'. Innovation 17: 97118.

Koopmans, Ruud and Paul Statham (2002) 'The transformation of political mobilisation and communication in European public spheres: A research outline'. http://europub.wzb.eu/project_design.en.htm, consulted March 2005.

Koopmans, Ruud and Paul Statham (1999) 'Political claims analysis: Integrating protest event and political discourse approaches'. Mobilisation: An International Journal 4: 40-51.

Kriesi, Hans-Peter; Edgar Grande; Romain Lachat, Martin Dolezal; SimonBornschier and Tim Frey. (2006) 'Globalization and the transformation of the national political space: six European countries compared'. European Journal of Political Research 45.(6): 921957.

Kunelius, Risto and Colin Sparks (2001) 'Problems with a European Public Sphere: An Introduction'. Javnost 8 (1): 5-20.

Neidhardt, Friedhelm; Ruud Koopmans and Barbara Pfetsch (2000) ,Konstitutionsbedingungen politischer Öffentlichkeit: der Fall Europa [Conditions for political public spheres: 
the case of Europe]', pp. 263-93 in WZB-Jahrbuch. Berlin, Wissenschaftszentrum Berlin für Sozialforschung.

Page, Benjamin. (1996) 'The Mass Media as Political Actors'. Political Science and Politics 29(1): $20-25$.

Page, Benjamin; Robert Y. Shapiro and Glenn R. Dempsey (1987) 'What moves public opinion?'. American Political Science Review 81(1): 23-43.

Peter, Jochen; Edmund Lauf and Holli Semetko (2004a) 'Television Coverage of the 1999 European Parliamentary Elections'. Political Communication 21: 415-433.

Peter, Jochen and Claes H. de Vreese. (2004b) 'In Search of Europe. A Cross-National Comparative Study of the European Union in National Television News'. The Harvard International Journal of Press / Politics 9 (3): 3-24.

Pfetsch, Barbara and Silke Adam (2008) ,Die Akteursperspektive in der politischen Kommunikationsforschung - Fragestellungen, Forschungsparadigmen und Problemlagen [The Actor's perspective in political communication research - questions, research paradigms and problems]', .pp.9-26 in B. Pfetsch and S. Adam (eds.) Massenmedien als politische Akteure. Konzepte und Analysen. Wiesbaden: VS.

Pfetsch, Barbara (2007) 'National Media in Europeanized Public Sphere: The Openness and Support of the Press for European Integration' pp.401-425. in: C. de Vreese, and H. Schmitt (eds.) A European Public Sphere: How much of it do we have and how much do we need?. Mannheim: CONNEX Report Series No 02. 
Risse, Thomas and Daniela Engelmann-Martin (2002) 'Ìdentity Politics and European Integration. The Case of Germany`, pp. 287-316 in A. Pagden (ed.) The Idea of Europe. From Antiquity to European Union. Cambridge: Cambridge University Press.

Scharpf, Fritz W. (1999) ,Demokratieprobleme in der Europäischen Mehrebenenpolitik [Problems of democracy within the multi-level system of EU politics]', pp. 672-94 in W. Merkel and A. Busch (eds.) Demokratie in Ost und West. Frankfurt a. M.: Suhrkamp.

Tobler, Stefan (2002) ,Transnationale Kommunikationsverdichtungen im Streit um die internationale Steuerpolitik' [Transnational communicative linkages in the struggle for international tax policies. Berliner Debatten Initial 13 (5/6): 67-78.

Trenz, Hans-Jörg (2005) ,Europa in den Medien. Die europäische Integration im Spiegel nationaler Öffentlichkeit [Europe in the media.]'. Frankfurt: Campus..

Van de Steeg, Marianne (2005) 'The public sphere in the European Union. A media analysis of public discourse on EU enlargement and on the Haider case', $\mathrm{PhD}$ dissertation, Florence, European University Institute.

Van de Steeg, Marianne (2002) 'Eine europäische Öffentlichkeit? Die Diskussion um die Osterweiterung der EU' [One European Public Sphere? A discussion on eastern enlargement of the European Union]. Berliner Debatten Initial 13 (5/6): 57-66. 
Voltmer, Katrin (1998/99) Medienqualität und Demokratie. Eine empirische Analyse publizistischer Informations- und Orientierungsleistungen in der Wahlkampfkommunikation [Media's quality and democracy. An empirical analysis of media's quality in giving information and orientation during elections]. Baden-Baden: Nomos. 
APPENDIX A

A1: Newspapers under study

\begin{tabular}{|l|l|l|l|l|}
\hline & \multicolumn{2}{|l|}{ Quality Presst } & Regional Press & Tabloid Press \\
\hline Germany & $\begin{array}{l}\text { Süddeutsche Zei- } \\
\text { tung }\end{array}$ & $\begin{array}{l}\text { Frankfurter Allge- } \\
\text { meine Zeitung }\end{array}$ & $\begin{array}{l}\text { Leipziger Volkszei- } \\
\text { tung }\end{array}$ & Bild-Zeitung \\
\hline Spain & El Pais & Abc & La Vanguardia & El Mundo \\
\hline France & Le Monde & Le Figaro & Ouest France & \\
\hline Italy & La Repubblica & $\begin{array}{l}\text { II Corriere della } \\
\text { Sera }\end{array}$ & $\begin{array}{l}\text { II Mattino } \\
\text { La Nazione }\end{array}$ & \\
\hline Netherlands & De Volkskant & $\begin{array}{l}\text { Het Algemeen } \\
\text { Dagblad }\end{array}$ & De Limburger & De Telegraaf \\
\hline $\begin{array}{l}\text { United King- } \\
\text { dom }\end{array}$ & The Guardian & The Times & The Scotsman & The Sun \\
\hline Switzerland & $\begin{array}{l}\text { Neue Zürcher } \\
\text { Zeitung }\end{array}$ & Le Temps & & $\begin{array}{l}\text { Blick } \\
\text { Le Matin }\end{array}$ \\
\hline
\end{tabular}

Note: In the case of the Netherlands, De Telegraaf fits best the Dutch conception of tabloid. In Italy instead of a tabloid, a second regional newspaper was chosen. In France no tabloid paper could be analyzed. L' Humanité, the paper of the Communist party that was analyzed neither fits the category of a regional nor of a tabloid paper. Therefore it was omitted in the analysis. 


\section{A2: Dimensions of conflict lines}

\begin{tabular}{|c|c|c|}
\hline $\begin{array}{l}\text { Type of con- } \\
\text { flict }\end{array}$ & Conflict Line & Dimensions \\
\hline $\begin{array}{l}\text { Fundamental } \\
\text { conflict }\end{array}$ & Membership & $\begin{array}{l}\text { - most suitable degree of regional involvement for Euro- } \\
\text { pean states (withdrawal, full involvement) }\end{array}$ \\
\hline \multirow[t]{2}{*}{$\begin{array}{l}\text { Institutional } \\
\text { conflict }\end{array}$} & $\begin{array}{l}\text { Relation between } \\
\text { member states }\end{array}$ & $\begin{array}{l}\text { - balance of member state power that works best for EU } \\
\text { (dominance, equal say) } \\
\text { - Europe a la carte (similar speed, different speeds) }\end{array}$ \\
\hline & $\begin{array}{l}\text { Relation between } \\
\text { mem. states and } \\
\text { EU }\end{array}$ & $\begin{array}{l}\text { - vision of fully functioning Europe (Europe of nations, } \\
\text { federal Europe) } \\
\text { - competent political organisations (sovereignty, suprana- } \\
\text { tionality) } \\
\text { - appropriate decision-making structures (national veto, } \\
\text { qualified majority) } \\
\text { - effective reform of EU structures (power to Council, } \\
\text { power to supranational institutions) } \\
\text { - defence of interests (national interest paramount, com- } \\
\text { mon interest paramount) } \\
\text { - values of EU member states (nationalism, cosmopolitan } \\
\text { values) } \\
\text { - level of problem solving (national level, EU level) }\end{array}$ \\
\hline \multirow[t]{2}{*}{$\begin{array}{l}\text { Conflict on role } \\
\text { of citizens }\end{array}$} & $\begin{array}{l}\text { Relation between } \\
\text { EU and citizens }\end{array}$ & $\begin{array}{l}\text { - functioning democracy (representative democracy, citi- } \\
\text { zen participation) } \\
\text { - level of accountability (sufficient, more rights for citizens) }\end{array}$ \\
\hline & Citzens' identity & $\begin{array}{l}\text { - sense of belonging (preservation of identities, change } \\
\text { towards plural identities) }\end{array}$ \\
\hline $\begin{array}{l}\text { Conflict on } \\
\text { goals of EU } \\
\text { integration }\end{array}$ & $\begin{array}{l}\text { Widening- deepen- } \\
\text { ing }\end{array}$ & $\begin{array}{l}\text { - depth of integration that works best for EU (more integra- } \\
\text { tion, less integration) } \\
\text { - appropriately sized EU (widen, don't widen) } \\
\text { - type of entity (economic trading bloc, also political / so- } \\
\text { cial entity) } \\
\text { - Reforms and enlargement (reforms before enlargement, } \\
\text { enlargement before reforms) }\end{array}$ \\
\hline \multirow[t]{3}{*}{$\begin{array}{l}\text { Conflict on role } \\
\text { of EU }\end{array}$} & Foreign policy & $\begin{array}{l}\text { - enhanced security for EU (traditional arrangements, } \\
\text { common arrangements) } \\
\text { - strength in global affairs (individual strength, common } \\
\text { strength) } \\
\text { - Europe's position in the world (common strength by inte- } \\
\text { gration, middle power without integration) }\end{array}$ \\
\hline & Monetary policy & $\begin{array}{l}\text { - strong EU economies (common monetary policy, tradi- } \\
\text { tional monetary policy) }\end{array}$ \\
\hline & Social policy & $\begin{array}{l}\text { - fully functioning and prosperous economy (liberalisation, } \\
\text { state intervention) } \\
\text { - responsibility for welfare (individual, state) }\end{array}$ \\
\hline
\end{tabular}




\section{Appendix B: Tables and Figures}

Figure 1: Openness towards European actors by country in the field of EU integration

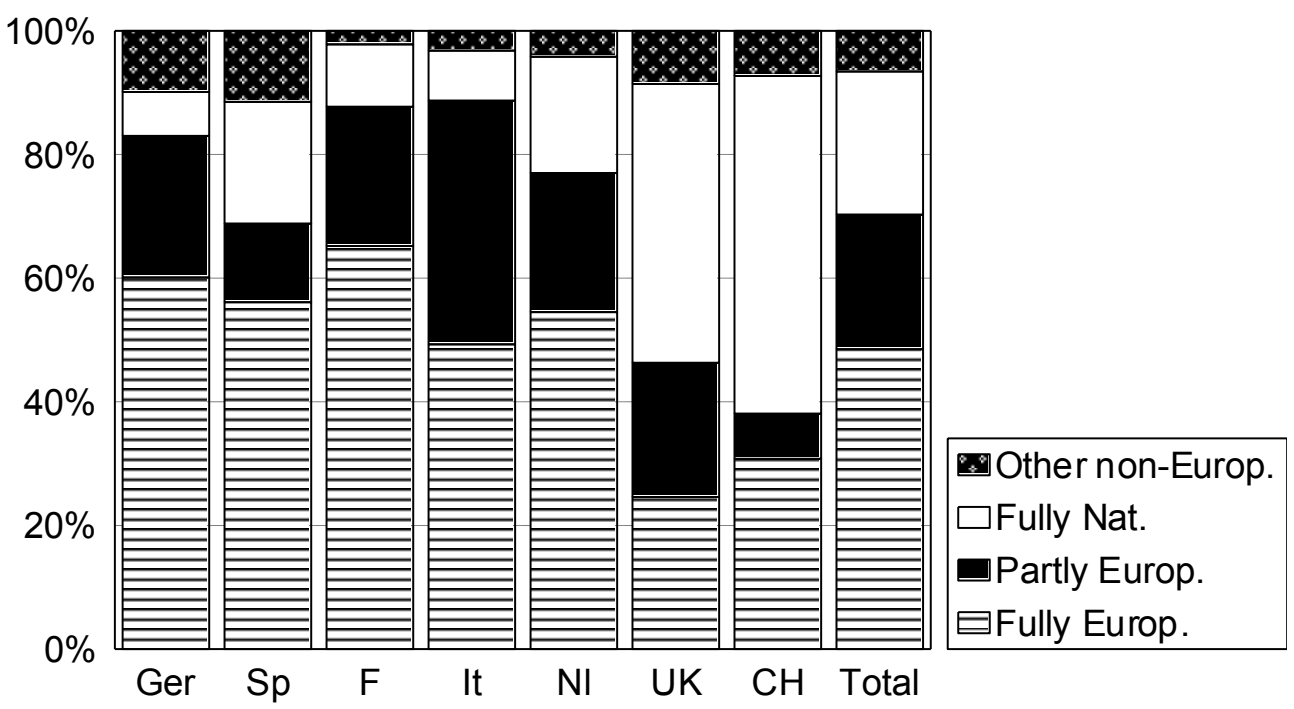

Basis: all claims of journalists where an addressee and / or affected actor is identified in the issue field of EU integration only ( $\mathrm{N}$ $(\mathrm{Ger})=253 ; \mathrm{N}(\mathrm{Sp})=157), \mathrm{N}(\mathrm{F})=178 ; \mathrm{N}(\mathrm{It})=221 ; \mathrm{N}(\mathrm{NI})=191 ; \mathrm{N}(\mathrm{UK})=175 ; \mathrm{N}(\mathrm{CH})=234 ; \mathrm{N}($ Total $)=1409)$.

Explanation of categories: Other non-Europ.: no EU / member state actors involved + not only national actors involved; Partly Europ.: half of the actors (addressees / affected actors) within a claim from the EU or member states; Fully Europ.: all actors (addressee / affected actors) within a claim from the EU or member states, fully nat. = all actors from the own nation state.

Note: The total column has been weighted by the number of EU-commentaries in each country so that each country contributes with the same share.

Reliability: Adressee $=83 \%$, Affected Actor $=88 \%$ 
Table 1: Issues on the commentary agenda of the national press

\begin{tabular}{|c|c|c|c|c|c|c|c|c|}
\hline$\%$ & Ger & $\mathrm{Sp}$ & $\mathrm{F}$ & It & $\mathrm{NI}$ & UK & $\mathrm{CH}$ & average* \\
\hline EU Integration & 28,4 & 31,3 & 42,3 & 32,3 & 26,5 & 19,6 & 40,8 & 31,6 \\
\hline \multirow[t]{2}{*}{6 other topics } & 71,6 & 68,7 & 57,7 & 67,7 & 73,5 & 80,4 & 59,2 & 68,4 \\
\hline & 100 & 100 & 100 & 100 & 100 & 100 & 100 & 100 \\
\hline \multirow[t]{2}{*}{$\mathrm{N}$} & 1004 & 595 & 447 & 694 & 732 & 910 & 681 & 5063 \\
\hline & $\nabla$ & $\downarrow$ & $\downarrow$ & $\downarrow$ & $\downarrow$ & $\nabla$ & $\nabla$ & \\
\hline $\begin{array}{l}\text { Share of EU integra- } \\
\text { tion in } \%\end{array}$ & Ger & Sp & $F$ & It & $\mathrm{NI}$ & UK & $\mathrm{CH}$ & average* $^{*}$ \\
\hline Quality press & 30,2 & 34,5 & 39,0 & 37,6 & 30,7 & 18,0 & 41,5 & 33,6 \\
\hline Regional press & 22,4 & 30,1 & 51,2 & 25,0 & 29,5 & 13,9 & -- & 29,3 \\
\hline Boulevard press & 14,3 & 23,5 & -- & -- & 18,0 & 29,4 & 38,1 & 25,6 \\
\hline N Quality & 821 & 307 & 326 & 402 & 355 & 511 & 547 & 3269 \\
\hline N Regional & 134 & 186 & 121 & 292 & 149 & 202 & -- & 1079 \\
\hline N Boulevard & 49 & 102 & -- & -- & 228 & 197 & 134 & 715 \\
\hline
\end{tabular}

Basis: all coded issue fields; 6 other topics: Monetary Politics, Agriculture, Immigration, Troops Deployment, Retirement / Pension Politics / Education.

* Note: The average column has been weighted by the number of commentaries in each country so that each country contributes with the same share.

Reliability: issue field $1=98 \%$; issue field $2=74 \%$; issue field $3=92 \%$ 
Table 2: Degree of Europeanization by media types and country - Means and Multiple Classification Analysis (MCA)

\begin{tabular}{|l|c|c|c|c|c|c|c|c|}
\hline Mean & Ger & Sp & F & It & NI & UK & CH & $\begin{array}{c}\text { aver- } \\
\text { age }^{*}\end{array}$ \\
\hline Quality & .71 & .54 & .75 & .67 & .70 & .46 & .40 & .61 \\
\hline Regional & .70 & .78 & .80 & .73 & .56 & .39 & & .68 \\
\hline Boulevard & .90 & .65 & & & .65 & .18 & .11 & .36 \\
\hline All media & .72 & .62 & .76 & .69 & .66 & .35 & .34 & .59 \\
\hline $\mathrm{N}$ & 253 & 157 & 178 & 221 & 191 & 175 & 234 & 1418 \\
\hline
\end{tabular}

\begin{tabular}{|l|c|c|c|}
\hline & \multicolumn{2}{|c|}{ Independent Variable } & Strength of model \\
\hline Dependent Var. (Mean) & Country (Beta) & Newspaper Type (Beta) & R-square \\
\hline Europeanization & $.34^{* \star *}$ & $.11^{* * *}$ & .15 \\
\hline
\end{tabular}

Basis: all claims of journalists where an addressee and / or affected actor is identified in the issue field of EU integration only Range: "0" (not Europeanised at all) to "1" (fully Europeanised); Significance: ${ }^{* * *}<0.01 ;{ }^{* *}<0.05 ;{ }^{*}<0,1$

${ }^{*}$ Note: The average column has been weighted by the number of EU-commentaries in each country so that each country contributes with the same share.:

Reliability: addressee $=83 \%$; affected actor $=88 \%$ 
Table 3: Conflict lines in the national press

\begin{tabular}{|c|c|c|c|c|c|c|c|c|c|}
\hline & $\%$ & Ger & Sp & $\mathrm{F}$ & It & $\mathrm{NI}$ & UK & $\mathrm{CH}$ & $\begin{array}{l}\text { aver- } \\
\text { age* }^{*}\end{array}$ \\
\hline $\begin{array}{l}\text { Fundamental } \\
\text { Conflict }\end{array}$ & $\begin{array}{l}\text { Membership } \\
\text { (yes - no) }\end{array}$ & & 1,1 & 6,1 & 2,9 & 0,8 & 4,8 & 67,6 & 10,6 \\
\hline \multirow[t]{2}{*}{$\begin{array}{l}\text { Institutional } \\
\text { Conflict }\end{array}$} & $\begin{array}{l}\text { Relation between } \\
\text { Member States }\end{array}$ & 9,6 & 6,7 & $\overline{8,1}$ & 7,2 & 5,9 & 0,8 & 5,0 & $\overline{6,1}$ \\
\hline & $\begin{array}{l}\text { Relation between } \\
\text { Mem. States \& EU }\end{array}$ & 33,8 & 30,3 & 43,9 & 41,3 & 39,8 & 20,0 & 9,4 & 31,9 \\
\hline \multirow{2}{*}{$\begin{array}{l}\text { Conflict on } \\
\text { role of citi- } \\
\text { zens }\end{array}$} & $\begin{array}{l}\text { Relation between } \\
\text { EU and citizens }\end{array}$ & 3,7 & 4,5 & 4,1 & 0,7 & 5,1 & 4,0 & 2,2 & $\overline{3,5}$ \\
\hline & Citizens (identity) & 1,5 & & & 3,6 & & & & 0,8 \\
\hline $\begin{array}{l}\text { Conflict on } \\
\text { goals of EU } \\
\text { integration }\end{array}$ & $\begin{array}{l}\text { Widening Deepen- } \\
\text { ing }\end{array}$ & 39,7 & 36,0 & 26,4 & 28,3 & 39,8 & 18,4 & 10,8 & $\overline{28,0}$ \\
\hline \multirow{3}{*}{$\begin{array}{l}\text { Conflict on } \\
\text { role of EU }\end{array}$} & Foreign policy & 9,6 & 10,1 & 5,4 & 15,2 & 4,2 & 17,6 & 4,3 & $\overline{9,7}$ \\
\hline & Monetary policy & 0,7 & 4,5 & 4,1 & 0,7 & 2,5 & 32,0 & 0,7 & 7,3 \\
\hline & Social policy & 1,5 & 6,7 & 2,0 & 0,0 & 1,7 & 2,4 & 0,0 & 2,0 \\
\hline \multirow{2}{*}{\multicolumn{2}{|c|}{$\mathrm{N}$}} & 100 & 100 & 100 & 100 & 100 & 100 & 100 & 100 \\
\hline & & 136 & 89 & 148 & 138 & 118 & 125 & 139 & 926 \\
\hline
\end{tabular}

Basis: most important conflict line employed by journalist in the issue field of EU integration only.

${ }^{*}$ Note: The average column has been weighted by the number of EU-commentaries in each country so that each country contributes with the same share.

Reliability: conflict line $1=82 \%$ 
Table 4: Press' position on dominant conflict lines

\begin{tabular}{|c|c|c|c|c|c|c|c|c|c|}
\hline & $\%$ & Ger & Sp & $\mathrm{F}$ & It & $\mathrm{NI}$ & UK & $\mathrm{CH}$ & $\begin{array}{l}\text { aver- } \\
\text { age* }^{*}\end{array}$ \\
\hline \multirow[t]{2}{*}{ Membership } & Withdrawel & & & 0,9 & & & 0,9 & & 0,3 \\
\hline & $\begin{array}{l}\text { Full involve- } \\
\text { ment }\end{array}$ & & & 5,2 & 2,2 & 1,1 & 1,9 & 67,5 & 8,0 \\
\hline \multirow{2}{*}{$\begin{array}{l}\text { Relation be- } \\
\text { tween Mem. } \\
\text { States \& EU }\end{array}$} & Intergov. & 7,1 & 3,4 & 1,7 & 7,6 & 6,7 & 20,4 & & 7,6 \\
\hline & Supranat. & 21,2 & 22,0 & 33,0 & 30,4 & 30,0 & 0,9 & 3,9 & 20,4 \\
\hline \multirow[t]{2}{*}{$\begin{array}{l}\text { Widening vs. } \\
\text { Deepening }\end{array}$} & $\begin{array}{l}\text { Focus: deep- } \\
\text { ening }\end{array}$ & 25,3 & 18,6 & 21,7 & 21,7 & 23,3 & 1,9 & 3,9 & 16,5 \\
\hline & $\begin{array}{l}\text { Focus: wid- } \\
\text { ening }\end{array}$ & 17,2 & 13,6 & 7,8 & 9,8 & 16,7 & 16,7 & 6,5 & 12,7 \\
\hline \multirow[t]{2}{*}{ Foreign Policy } & Traditional & 1,0 & 1,7 & & 2,2 & 2,2 & 11,1 & & 3,2 \\
\hline & Common & 8,1 & 15,3 & 8,7 & 14,1 & 2,2 & 5,6 & 5,2 & 8,2 \\
\hline \multirow{3}{*}{$\begin{array}{l}\text { Monetary Poli- } \\
\text { cy }\end{array}$} & Traditional & & & & & & 31,5 & & 6,4 \\
\hline & Common & 1,0 & 5,1 & 5,2 & 1,1 & 2,2 & 1,9 & & 2,6 \\
\hline & $\begin{array}{l}\text { Other posi- } \\
\text { tions }\end{array}$ & 19,1 & 20,3 & 15,8 & 10,9 & 15,6 & 7,2 & 13,0 & 14,1 \\
\hline & & 100 & 100 & 100 & 100 & 100 & 100 & 100 & 100 \\
\hline \multicolumn{2}{|l|}{$\mathrm{N}$} & 99 & 59 & 115 & 92 & 90 & 108 & 77 & 661 \\
\hline
\end{tabular}

Basis: position taken by journalist on most important conflict line employed in the issue field of EU integration only.

* Note: The average column has been weighted by the number of EU-commentaries in each country so that each country contributes with the same share.

Note: Only the dominant conflict lines are presented here. Additionally, the case numbers are lower than in table 2 as only explicit positions have been analyzed.

Reliability: conflict line $1=82 \%$ 